logos_i_ethos_1_(32)_2012, s. 105-126

Grzegorz Hołub

\title{
Człowiek a świat naturalny. Wokół koncepcji egalitaryzmu gatunkowego Paula W. Taylora
}

\section{Zwrot biocentryczny}

Etyczna refleksja nad środowiskiem wydaje się koniecznym elementem namysłu nad światem, w którym żyjemy. Postępująca degradacja środowiska naturalnego

ks. Grzegorz Hołub - dr hab. filozofii, adiunkt na Wydziale Filozoficznym Uniwersytetu Papieskiego Jana Pawła II w Krakowie. Zajmuje się bioetyką i filozofią człowieka.

zmusza do postawienia pytania o genezę tego procesu i o sposoby jego ograniczenia. Etyka środowiskowa, która jest przestrzenią dla takiego specyficznego namysłu, zawiera już dzisiaj parę stanowisk teoretycznych, które oferują odmienną diagnozę i remedium na szerzący się kryzys ekologiczny. Obok antropocentryzmu, nie-antropocentryzmu-„,sentientyzmu", ekocentryzmu, ekofeminizmu i głębokiej ekologii, ważne debaty toczą się w ramach tak zwanego biocentryzmu. W nurcie tym utrzymuje się, że aby zahamować niekorzystne zmiany w środowisku, należy dokonać odmiennego spojrzenia na świat. Należy uzmysłowić sobie, że w centrum istniejącego świata nie jest tylko istota ludzka, ale wagę posiada każda istota, w której dokonuje się dynamiczny proces życia. Biocentryzm znajduje się więc w zasadniczej opozycji do antropocentryzmu (człowiekowi przysługuje centralna pozycja w świecie) i poniekąd do nie-antropocentryzmu-,,sentientyzmu” (w centrum są istoty zdolne do odczuwania). Za głównych inicjatorów tego poszerzonego spojrzenia na naturalny świat uważa się w filozofii takie postacie, jak: Albert Schweitzer, Kenneth Goodpaster, Robin Attfield i Paul W. Taylor ${ }^{1}$. W polskiej refleksji filozoficznej stanowisko takie reprezentuje Zdzisława Piątek.

Zob. J. B. Callicott, Environmental Ethics, [w:] Encyclopedia of Bioethics, red. S. G. Post, t. 2, New York 2003, s. 760. 
W artykule tym, w centrum analiz znajdą się jedynie poglądy Paula Taylora, a precyzyjnie mówiąc - jego koncepcja egalitaryzmu biocentrycznego (egalitaryzmu gatunkowego). Jest to bowiem projekt, któremu filozof poświęcił wiele miejsca i energii, a który zarazem jawi się jako kontrowersyjny. Skłania więc do analizy i przemyśleń, a w końcu do stwierdzenia, w jakim stopniu jest wiarygodny. Taylor dokonał prezentacji tej koncepcji poprzez sformułowanie czterech tez. I one to staną się głównym przedmiotem namysłu. Będzie więc chodziło o prześledzenie ich znaczenia, zależności pomiędzy nimi, i dokonanie krytycznego spojrzenia na nie, wraz z przedstawieniem pozytywnej propozycji rozwiązania wyłaniających się z nich dylematów.

Na wstępie należy jeszcze wyraźnie określić profil etyczny namysłu Paula Taylora. Prezentowana przez niego refleksja sprawia, że przekroczone zostają ramy etyki tradycyjnej, odnoszącej się zasadniczo do jednostek ludzkich i relacji międzyludzkich, w obrębie wspólnoty Homo sapiens. Ten zwrot wynika z tego, że amerykański myśliciel dostrzega konieczność objęcia refleksją etyczną także świat pozaludzki. Wymóg ten sygnalizowany jest już w podanej przez Taylora definicji etyki środowiskowej, którą określił jako refleksję nad „moralną relacją zachodzącą pomiędzy ludźmi, a naturalnym światem”2. Przez to można powiedzieć, że filozof ten zainicjował nowy typ namysłu etycznego, gdzie moralna doniosłość wynika $\mathrm{z}$ innego rozumienia zjawiska życia. Jest to typ etyki dla bio-wspólnoty, gdzie człowiek jest tylko jednym z gatunków i gdzie zasadniczo akcent położony jest na fenomenie życia całego naturalnego świata (wild life).

\section{Tezy egalitaryzmu gatunkowego}

W swojej książce zatytułowanej Szacunek dla natury. Teoria etyki środowiskowej (Respect for Nature. A Theory of Environmental Ethics), Paul Taylor formułuje cztery zasadnicze tezy, dotyczące statusu istot żywych i relacji, jakie je łączą. Tezy te brzmią następująco: 
(1) Ludzie są członkami ziemskiej wspólnoty życia w tym samym znaczeniu i na tych samych warunkach, jak inne żyjące istoty.

(2) Gatunek ludzki, wraz z innymi gatunkami, jest integralnym składnikiem systemu wzajemnej zależności. Przeżycie każdej istoty - jak również jej szanse na pomyślne bądź niepomyślne życie - jest określone nie tylko przez fizyczne warunki jej środowiska, ale także przez jej relacje $z$ innymi żyjącymi istotami.

(3) Wszystkie organizmy są teleologicznymi centrami życia, w tym znaczeniu, że każdy jest niepowtarzalną jednostką, dążącą do własnego dobra, w swoisty sposób.

(4) Z natury ludzie nie są wyższymi stworzeniami od innych żyjących istot ${ }^{3}$.

Taylor wypracował dla tych twierdzeń odpowiednie znaczenia. Konieczne jest więc szczegółowe przyjrzenie się intencjom autora, a także prześledzenie zasadniczych aspektów, jakie filozof ten dostrzegł i rozwinął $\mathrm{w}$ ramach tych tez, które określił również mianem przekonań (beliefs). Ważne jest również zaznaczenie w tym miejscu istotnego założenia, przyjmowanego przez Taylora. Otóż myśliciel ten analizuje status istot i zachodzących pomiędzy nimi relacji, biorąc zasadniczo pod uwagę to, co je łączy. W odniesieniu do istot ludzkich jest przekonany, że jesteśmy członkami gatunku biologicznego i to określa podstawową cechę naszego istnienia. Stąd choć uznaje istniejące różnice pomiędzy człowiekiem a resztą przyrody, to jednak nie jest nimi zainteresowany; odsuwa je poniekąd na bok ${ }^{4}$.

\subsection{Człowiek obywatelem ziemskiej wspólnoty życia}

W ramach pierwszej tezy Taylor wyszczególnia pięć różnych aspektów. Pierwszy z nich wskazuje na biologiczne i fizyczne wymogi istnienia i przetrwania, które człowiek dzieli z innymi istotami naturalnego

3 Zob. tamże, s. 99-100. Wcześniej autor sformułował te tezy w artykule: The Ethics of Respect for Nature, „Environmental Ethics”, t. 3, 1981, s. 197-218.

Zob. P. W. Taylor, Respect for Nature..., dz. cyt., s. 101. 
świata. Wszystkie istoty, które zamieszkują naszą planetę, są uzależnione w swoim trwaniu od relacji ze środowiskiem naturalnym. To uzależnienie ma istotny wpływ na rozwój dalszych własności, to znaczy że wiele dalszych cech danej formy życia nie może pojawić się, o ile nie ma odpowiednich warunków fizycznych i biologicznych otoczenia. Taylor powie w odniesieniu do człowieka, że „samo przeżycie i co najmniej minimalny poziom zdrowia i sił są koniecznymi warunkami podążania za innymi wartościami ludzkimi”"

Drugi aspekt tego twierdzenia wskazuje na dobro własne danego istnienia. Każde istnienie - tak ludzkie, jak i pozaludzkie - posiada właściwe dla siebie dobro i jego realizacja zależy od uwarunkowań, które nie zawsze są pod naszą kontrolą. Taylor mówiąc o dobru własnym danego istnienia, ma na myśli dobro związane z życiem i rozwojem, pomijając relacje do innych istnień. Wskazuje on, że ,jeśli możemy powiedzieć [...], że coś jest dobre, albo złe, dla danego stworzenia bez odniesienia do innego istnienia, wówczas chodzi o dobro własne tegoż stworzenia" ${ }^{6}$. Realizacja takiego dobra, nawet w wypadku człowieka, nie jest całkowicie uzależniona od jego wysiłków. Filozof ten wskazuje, że zanegowanie tej prawdy jest przejawem arogancji i iluzorycznej wyniosłości człowieka, a efekty tego samooszukiwania się są negatywnie doświadczane w naszym życiu? .

Trzeci aspekt tej pierwszej tezy dotyczy wolnej woli, autonomii i wolności społecznej. W podstawowym wymiarze dotyczą one tylko człowieka. Tylko człowiek zdolny jest bowiem do dokonania wyborów pomiędzy różnymi alternatywami, kierując się własnym poznaniem racjonalnym. Ponadto, tylko człowiek może wyznaczać sobie cele do osiągnięcia i w ten sposób kształtować swoją przyszłość. W końcu tylko człowiek może cieszyć się tak zwaną wolnością społeczną czy polityczną. Chodzi tu o możliwość wpływu na struktury społeczne i polityczne, które określają warunki życia jednostki. Jednak w przekonaniu Taylora istnieje

Tamże, s. 103.

Tamże, s. 61.

Zob. tamże, s. 104 . 
jeszcze jeden, czwarty, wymiar wolności, który można wiarygodnie odnieść do wszystkich istnień w ziemskiej wspólnocie życia. Filozof ten tak go określa: „Bycie wolnym, w tym znaczeniu, oznacza bycie zdolnym do zachowania swojej egzystencji i promocji swojego dobra; bycie pozbawionym wolności, z kolei, to niezdolność do realizacji tych działań”.

To rozumienie wolności, jak twierdzi Taylor, bliskie jest pojęciu „braku przymusu”. Chodzi tu o niezależność od różnych typów przymusu. Filozof ten wskazuje na następujące ich rodzaje: przymus zewnętrzny i wewnętrzny; aktywny i bierny. Zewnętrzny łączy się zwykle z okolicznościami czy czynnikami zewnętrznymi względem jednostki. Wewnętrzne typy przymusu z kolei to obecne $\mathrm{w}$ jednostce bodźce lub stany. Aktywne wiążą się z działalnością jakiegoś czynnika; natomiast bierne oznaczają brak czegoś koniecznego - bycie pozbawionym czegoś. I tak Taylor formułuje następujące pary różnych uzależnień: (a) zewnętrzne aktywne - np. zamknięte drzwi, obecność zapory z drutu kolczastego, przemoc fizyczna czy tortury; (b) wewnętrzne aktywne - myśli obsesyjne, kompulsywne i wymykające się kontroli pragnienia, ekstremalne potrzeby fizjologiczne, takie jak potrzeba pożywienia, snu; (c) zewnętrzne bierne - brak pieniędzy, pożywienia, wody pitnej, opieki medycznej; (d) wewnętrzne bierne - brak wiedzy, kwalifikacji zawodowych, słabe zdrowie, upośledzenie fizyczne i psychiczne ${ }^{9}$.

Tego typu wolność w znacznej mierze odnosi się do jednostek ludzkich. Taylor jednak twierdzi, że można ten typ myślenia odnieść także do zwierząt i roślin. Za każdym razem, kiedy organizm - tak sensytywny, jak i wegetatywny - ma możliwość realizowania własnego dobra we właściwy sobie sposób (realizacja funkcji biologicznych), można orzec o nim, że jest wolny. Filozof ten stwierdza otwarcie:

organizm można uznać za wolny, jeśli posiada zdolność i sposobność do promowania i ochrony swego dobra, zgodnie z prawami swojej własnej natury.

Tamże, s. 106.

Tamże, s. 107n. 
W zakresie, w którym istnieją ograniczenia utrudniające albo uniemożliwiające organizmowi realizację dobra własnego, jest on wolności pozbawiony ${ }^{10}$.

Typy zniewolenia, jakie można wyszczególnić u istnień pozaludzkich wiążą się z utrudnieniami w realizacji własnego dobra $\mathrm{z}$ powodu warunków środowiskowych, braku odpowiednich środków do promocji i ochrony dobra własnego, anomalii zdrowotnych, czy z powodu braku normalnych własności, jak, na przykład, nabyta wada wzroku ${ }^{11}$.

U zwierząt najłatwiej rozpoznawalnym objawem braku wolności jest ograniczenie w swobodnym poruszaniu się, na skutek uwięzienia w klatce, w pułapce, na łańcuchu. Odzyskanie wolności będzie więc polegało na usunięciu tych ograniczeń. U roślin - jak zauważa Taylor - również można wskazać na objawy zniewolenia i konsekwentnie na sposoby uwalniania się od nich. Przykładem zniewolenia rośliny (drzewa, krzewu) jest brak miejsca do swobodnego wzrostu, kiedy jej korzenie są znajdują się w zbyt małym pojemniku. Przeniesienie rośliny do środowiska naturalnego będzie typem uwolnienia, zwrócenia jej wolności.

W powyższych analizach omawiany jest pewien podstawowy rodzaj wolności. Odnosi się on tak do ludzi, jak i do zwierząt i roślin. Ta wolność, jako brak ograniczeń pozytywnych i negatywnych, jest instrumentalnym dobrem dla wszystkich istot. Dzięki niej każde stworzenie może realizować swoje dobro podstawowe, jakim jest swobodna ekspresja swojego istnienia. Jak powie Taylor, w tym kontekście: „być wolnym, to posiadać większą szansę na przeżycie najlepszego rodzaju istnienia, do jakiego jesteśmy uzdolnieni”12.

Czwarty aspekt tej pierwszej tezy odnosi się do wspólnej genezy człowieka i innych gatunków zamieszkujących ziemię. Taylor wskazuje, że jednostki Homo sapiens pojawiły się na mocy działania mechanizmów ewolucji, selekcji naturalnej i dziedziczenia genów, tak jak każdy

Tamże, s. 109.

Zob. tamże.

12 Tamże, s. 111. 
inny żyjący organizm. W skazuje on nawet, że człowiek jest stosunkowo „nowym przybyszem” i przed nim były już obecne inne gatunki, które utworzyły sieci wzajemnych relacji i oddziaływań. Taylor, opierając się na szacunkowych danych, mówi, że człowiek pojawił się na ziemi 400000 albo 500000 lat temu. Jest to stosunkowo krótki czas, w porównaniu do geologicznego wieku ziemi.

System, dzięki któremu człowiek mógł pojawić się na tej planecie, działał już dużo wcześniej. I tylko dzięki jego sprawnemu funkcjonowaniu pojawienie się jednostek ludzkich stało się możliwe. Takie postawienie sprawy prowadzi Taylora do stwierdzenia, że „nie powinniśmy już dłużej postrzegać siebie jako specjalnych celów stworzenia. Jesteśmy produktem systemu, który zrodził także każdy inny typ żyjącej istoty"13. Chodzi tu oczywiście o proces ewolucji. Jego „elementy, które sterowały naszym pojawieniem się, nie były odmienne od tych, które spowodowały zaistnienie innych istot"14. Twierdzenie, że pojawienie się człowieka było kulminacją procesów ewolucji jest - według tego filozofa - wyrazem ludzkiej próżności.

Piątym aspektem tej pierwszej tezy Taylora jest wskazanie na zależność człowieka od ziemskiego systemu ekologicznego i na niekonieczność ludzkiej obecności w nim. Filozof ten wskazuje, że jednostki ludzkie są całkowicie zależne w swoim istnieniu od kondycji środowiska naturalnego, czego nie można wykazać w relacji odwrotnej. „Zdrowie” i harmonia ziemskiej biosfery w najmniejszym stopniu nie są zależne od człowieka. Tylko człowiek nie jest zdolny do trwania i ochrony samego siebie bez pomocy naturalnego porządku natury. $\mathrm{O}$ ile porządek ten jest nienaruszony, przynajmniej w swoich fundamentach, o tyle istoty ludzkie mogą trwać i swobodnie rozwijać się. Jak powie Taylor: „nasza zależność od dobrej kondycji całej sfery życia jest absolutna”"15. Tak więc radykalne i niekorzystne zamiany w środowisku niosą poważne zagrożenie dla przetrwania gatunku ludzkiego.

Tamże, s. 112.

Tamże.

Tamże, s. 114. 
Tego nie można powiedzieć o relacji przeciwnej. Kryzys istot ludzkich, skutkujący ich wymieraniem, a nawet całkowitym zaniknięciem, nie powinien wywrzeć negatywnego wpływu na biosferę. Ziemia ze swoimi naturalnymi systemami nadal będzie istniała, chyba żeby to zniknięcie jednostek Homo sapiens było zarazem unicestwieniem naturalnego świata (na skutek np. wojny jądrowej). W innej jednak sytuacji, np. w wyniku wyginięcia jednostek Homo sapiens na skutek chorób typowo ludzkich, środowisko będzie nadal trwało. Mało tego, naturalny świat odniesie swoistą korzyść ze zniknięcia człowieka. Ziemska wspólnota życia, jako całość, odniesie korzyść z faktu nieobecności istoty ludzkiej. Taylor mówi tu o zaprzestaniu niszczenia naturalnych siedlisk (habitats), które dokonywało i dokonuje się przez budowę osiedli, fabryk czy lotnisk.

Odejście człowieka $\mathrm{z}$ tego świata to również koniec degradacji środowiska na skutek szerokiego zastosowania zdobyczy współczesnych technologii, niekontrolowanego przyrostu naturalnego czy nadmiernej konsumpcji. Filozof ten wprost wskazuje na dobroczynne skutki nieobecności ludzkiej na ziemi: ekosystemy powrócą do swej równowagi, lasy tropikalne odzyskają swój dobroczynny wpływ na klimat planety, zanieczyszczone morza i oceny uwolnią się - po upływie paru stuleci - od trujących substancji. Jedynymi czynnikami, które mogą zakłócać harmonię środowiskową, będą wybuchy wulkanów czy okresy zlodowacenia. Taylor jest przekonany, że ziemska wspólnota życia, uwolniona od człowieka, odzyska swoją witalność i dynamikę rozwojową. Stwierdza on:

ostateczne zniknięcie Homo sapiens nie tylko sprawi, że ziemska wspólnota życia będzie nadal istniała, ale - według wszelkiego prawdopodobieństwa - jej dobrostan się poprawi. Nasza ludzka obecność nie jest tu więc potrzebna ${ }^{16}$.

\subsection{Gatunek ludzki w sieci zależności}

Druga teza Taylora podejmuje wątek wzajemnych zależności, jakie występują pomiędzy organizmami przynależącymi do ziemskiej 
wspólnoty życia. Chodzi tu zarówno o powiązania i zależności pomiędzy jednostkami, jak i pomiędzy gatunkami. Cały naturalny świat cechuje się bogatą kompleksowością wzajemnych relacji, zależności i odniesień. Powstaje w ten sposób pewna złożona sieć ekosystemów. Jak powie ten filozof:

wszystkie różniące się ekosystemy, które tworzą ziemską biosferę, są dopasowane do siebie w taki sposób, że kiedy jeden zostanie radykalnie zmieniony czy całkowicie zniszczony, w innych dokonuje się modyfikacja i w całości struktury następuje zmiana ${ }^{17}$.

To pokazuje, że żadnego ekosystemu i wchodzących w jego skład istot żyjących nie można rozpatrywać w oderwaniu od innych elementów tego typu. Żaden z nich nie jest wyizolowaną całością. To, co dokonuje się w jednym ekosystemie, ma wpływ na inny. Tę złożoną całość Taylor określa mianem „naturalnego świata” ${ }^{18}$.

Teza ta niesie jasne implikacje dla istoty ludzkiej. Tak, jak każda inna istota żyjąca, człowiek jest częścią ziemskiej wspólnoty życia. W swoim istnieniu i rozwoju jest on uzależniony od innych istot i ekosystemów. Człowiek więc nie może ich niszczyć ani radykalnie osłabiać, ponieważ takim działaniem pomniejsza swoje szanse na przetrwanie i realizację specyficznie ludzkich wartości.

Taylor nie opowiada się jednak za etyką o charakterze holistycznym czy organicystycznym. Nie chce on powiedzieć, że wzajemne powiązania organizmów i ekosystemów tworzą jakiś quasi-organizm i że z jego funkcjonowania wynikają konkretne normy moralne. W tej bowiem sytuacji norma postępowania moralnego określana byłaby z punktu widzenia tej całości: jej dobra, witalności, dynamizmu. Pomimo dostrzeżenia szerokiej sieci wzajemnych powiązań, Taylor opowiada się za wyszczególnieniem wartości każdego pojedynczego istnienia, jako osobnego dobra. Ono dopiero wyznacza (rodzi) prawa: 
prawo do jego ekspresji i realizacji, i wynikające $\mathrm{z}$ niego obowiązki - obowiązek zachowania i promowania tego dobra po stronie tych, którzy są go świadomi ${ }^{19}$.

\subsection{Organizmy jako teleologiczne centra życia}

Trzecia teza Taylora wskazuje na fakt, że wszystkie istoty żyjące są teleologicznymi centrami życia. Każdy jest jednostką, która dąży do realizacji własnego, wewnętrznego dobra. Jego poznawcze ujęcie dokonuje się w pewnych etapach.

Filozof ten wskazuje najpierw, że poznanie struktury organizmów pozwala lepiej zrozumieć ich życie i rozwój, według praw właściwych dla danego gatunku, ale także ich oddziaływanie na inne żyjące istoty. W dalszej kolejności prowadzi to do poznania tych żyjących organizmów, jako jedynych w swoim rodzaju istnień, jako pewnych indywiduów. Taylor mówi w tym kontekście o pracy naukowców, którzy prowadząc badania nad organizmami żyjącymi, dostrzegają ich wyjątkowość: „bliska [ich] obserwacja na przestrzeni czasu, czy to w laboratorium czy w terenie, prowadzi [eksperymentatorów] do uznania specyficznej «osobowości» przedmiotu ich badań”20.

Nie jest to zresztą przywilej samych naukowców. Taylor jest przekonany, że każdy amator przyrody może odkryć tę indywidualność roślin i zwierząt. Dłuższe obcowanie z jednostką żyjącą, połączone z uważną obserwacją, pozwala na ukształtowanie sobie opinii, że żyje ona w specyficzny sposób. Taylor jest przekonany, że taki obserwator może nawet zaangażować się w los tej istoty, w doznawane powodzenia czy niepowodzenia. Twierdzi on, że

organizm [taki] nabiera dla obserwatora znaczenia jako jedyna, niezastępowalna jednostka. Wskutek tego nabywa on autentycznego zrozumienia dla

\footnotetext{
19 Zob. tamże, s. 118.

20 Tamże, s. 120.
} 
jej postrzegania świata. Obserwator może, za pomocą wyobraźni, postawić się w sytuacji tego organizmu i popatrzeć na świat $\mathrm{z}$ jego punktu widzenia ${ }^{21}$.

To przejście od obiektywnej wiedzy o jednostce do uznania jej indywidualności i w końcu do uświadomienia sobie jej punktu widzenia jest - w opinii Taylora - ujęciem tego, co określamy poznaniem jednostkowej istoty żyjącej.

Dzięki temu uczymy się, co to znaczy ujmować dany organizm jako teleologiczne centrum życia, które dąży do zachowania samego siebie i realizacji swojego dobra, w sobie tylko właściwy sposób ${ }^{22}$. W wypadku danej istoty nie musi to być dążenie świadome. Tak rośliny, jak i zwierzęta pozostają teleologicznymi centrami życia, nawet gdy nie zdają sobie z tego sprawy i nie podejmują żadnych intencjonalnych aktywności, skierowanych na osiągnięcie swych celów. Taylor powie, że:

wszystkie organizmy, czy to świadome, czy świadomości pozbawione, są teleologicznymi centrami życia w znaczeniu, że każdy z nich stanowi zunifikowany i spójnie zorganizowany system działań, skierowany na osiągnięcie celu. System ten charakteryzuje się niezmienną tendencją do ochrony i utrzymania istnienia organizmu ${ }^{23}$.

Indywidualny punkt widzenia, który wiąże się ze specyficzną „osobowością" rośliny czy zwierzęcia, jest wyznaczony przez jedyny w swoim rodzaju sposób, w jaki odpowiadają one na bodźce środowiskowe, oddziałują z innymi organizmami, i w jaki przechodzą różne zmiany, określone cyklami życia i rozwoju danego gatunku. Ten indywidualny punkt widzenia rośliny czy zwierzęcia człowiek może poznać, kiedy spojrzy na te istnienia w obiektywny sposób, czyli z zawieszeniem swoich odczuć, intencji czy interesów. Ponadto stanie się to możliwe, kiedy jednostka ludzka zdobędzie się na pewną integralność spojrzenia. Chodzi tu o zdystansowanie 
się od pojedynczych aspektów, w jakich zwykle jawią się człowiekowi rośliny i zwierzęta, ze względu na ich użyteczność czy funkcję w ludzkim działaniu (przykładem tej jednoaspektowości jest sposób, w jaki myśliwy postrzega bażanta). Chodzi tu o pozytywne postrzeganie istnień pozaludzkich, jako wieloaspektowych stworzeń, które realizują swój własny rodzaj istnienia, odpowiadając w specyficzny sposób na konkretne okoliczności środowiska, z którymi muszą się zmagać ${ }^{24}$.

Tego typu przemiana w ludzkich postawach sprawia, że ludzka świadomość ulega rozszerzeniu. Jest to moment, w którym człowiek może ukształtować w sobie głębszą wrażliwość na świat pozaludzkich istnień. Jak twierdzi Taylor, nabywając zdolności do przyjęcia punktu widzenia tych innych stworzeń, może wydać sąd, w oparciu o ich własne dobro. Filozof ten powie:

postrzegając je jak nas samych, gotowi jesteśmy przypisać im wartość, jaką przypisujemy sobie samym. Jeśli [my ludzie] uznajemy siebie za tych, którzy posiadają wewnętrzną wartość, tak samo będziemy gotowi czynić w odniesieniu do nich ${ }^{25}$.

\subsection{Człowiek równy innym istotom}

Ostatnia teza Taylora kwestionuje wyższość człowieka nad innymi istotami. Filozof ten jest przekonany, że jeśli zaakceptowaliśmy dotychczasowe twierdzenia, to będziemy skłonni zaakceptować także to ostatnie. Jednak podejmuje on dalszą próbę, aby osobno wykazać zasadność tego przekonania.

Taylor zauważa, że twierdzenie o wyższości człowieka nad innymi żyjącymi jednostkami wynika z przekonania o posiadaniu przez niego pewnych własności, których one nie posiadają. Problem, jaki tu dostrzega, to ten, że taki argument może być skierowany przeciwko człowiekowi. Nie posiada on bowiem tego, co posiadają istoty pozaludzkie, albo też

24 Taylor powie: „Insofar as we are able to achieve wholeness of vision in our grasp of an organism's uniqueness, we come to know the life of that individual as it is lived by it. We then conceive of it as a complete, many-faceted being carrying out its own mode of existence, responding in its own way to the particular circumstances confronting it" (tamże, s. 127).

25 Tamże, s. 128. 
dysponuje tym w uboższym zakresie. Możliwym rozstrzygnięciem tego problemu jest stwierdzenie, że to, co cechuje człowieka, jest bardziej wartościowe niż to, co wyróżnia rośliny i zwierzęta. Racjonalność, kreatywność estetyczna, indywidualna autonomia, wolna wola mogą być uznane za te specyficznie ludzkie własności, ukazujące jego wyższość. Filozof ten jednak pyta: dla kogo i z jakich powodów te ludzkie cechy są wartościowe? Niewątpliwie ich waga jest oceniana $z$ ludzkiego punktu widzenia, $w$ kontekście ludzkiego życia i spełnienia. Kiedy natomiast człowiek przyjmie postawę, o które wspomniano powyżej, to znaczy popatrzy na rośliny czy zwierzęta z ich punktów widzenia, dojdzie do całkiem innych wniosków ${ }^{26}$.

To spojrzenie na pozaludzkie istnienia $\mathrm{z}$ ich własnego punktu widzenia ujawnia, że jedynym wiarygodnym sposobem oceny jest powstrzymanie się od posługiwania się ludzkimi wartościami jako miarami oceny. Konieczne jest natomiast operowanie wartościami, które są adekwatne dla nich, dla ich gatunku i spełnienia. Tak więc dobro, powiedzmy, właściwe dla rodziny szympansów wyznacza kryteria oceny osobnika przynależącego do tej grupy. Na tyle, na ile dana jednostka realizuje to dobro, na tyle może być określona jako lepsza albo gorsza od innej jednostki tego samego gatunku. Taylor powie więc, że dane istnienie może być ocenione jako wyższe w stosunku do innego, o ile jedno i drugie podpada pod ten sam standard oceny ${ }^{27}$. Rośliny i zwierzęta nie mogą być uznane za niższe w stosunku do człowieka, kiedy nie spełniają tego, co spełnia człowiek. Cele człowieka nie są celami, na których osiągnięcie nastawione są inne istoty.

Posiadany przez jednostkę ludzką rozum, w opinii tego filozofa, nie może być cechą, która przechyla szalę wartości na jego korzyść. Człowiek potrzebuje władz rozumowych do realizacji swego ludzkiego dobra i ludzkich celów. Jest to więc własność, bez której nie mógłby być sobą. Tego jednak nie można powiedzieć o innych istotach, czy to sensytywnych, czy wegetatywnych. One bowiem realizują swoje dobra i cele bez użycia rozumu: rozum nie jest im potrzebny do spełnienia 
ich istnienia ${ }^{28}$. Jak stwierdza Taylor: „to, że realizacja ludzkiego dobra wymaga właściwego użycia rozumu w kierowaniu życiem, nie mówi nam nic o wartości życia tych istot, których celem nie jest osiągnięcie ludzkiego dobra"29. Filozof podejmuje próbę osłabienia głęboko zakorzenionego w filozofii europejskiej przekonania o szczególnej funkcji istot rozumnych. Stwierdza on: „musimy zdać sobie sprawę z tego, że racjonalność jest najwyżej jedną ze zdolności pewnej klasy żyjących istot, które polegają na niej w realizacji swojego dobrostanu"30.

Konsekwentnie Taylor wygłasza zasadniczą dla swej koncepcji tezę o równości gatunkowej. Tak rośliny, zwierzęta, jak i ludzie posiadają równą wartość. Na mocy tego my ludzie mamy takie same obowiązki prima facie względem nich, jak względem innych ludzi. Dobro roślin i zwierząt musi być brane pod wagę tak samo poważnie, jak dobro innych jednostek Homo sapiens. Filozof formułuje zasadę bezstronności gatunkowej (the principle of species-impartiality), stwierdzając: każdy gatunek zamieszkujący ziemię liczy się tak samo, posiada równe względem innych dobro i to dobro wymusza na działającym równy stopień zaangażowania. Dobro poszczególnych istot powinno być zachowane i strzeżone, jako cel sam w sobie. Wszystkie istoty posiadają równe dobra wewnętrzne i w związku $\mathrm{z}$ tym żadne nie może być oceniane jako wyższe albo niższe ${ }^{31}$.

\section{Krytyczne spojrzenie na tezy egalitaryzmu gatunkowego}

Przedstawione powyżej poglądy Paula Taylora dotykają zasadniczych kwestii w spojrzeniu na otaczający świat. Należy więc przyjrzeć się im

28 Jednak nawet brak czynnych władz rozumowych nie oznacza, że istoty te nie działają racjonalnie. $Z$ obserwacji wiemy bowiem, że spełniane przez nie funkcje (odżywianie się, obrona czy rozmnażanie się) są poniekąd rozumne i dokonują się w pewnym rozumnym porządku, który można poznać i ustalić jego prawidłowość. Tak więc tendencje rozumne są wpisane, w pewien sposób, w życie zwierząt.

29 P. W. Taylor, Respect for Nature..., dz. cyt., s. 137.

30 Tamże, s. 138.

31 Zob. tamże, s. 155. 
uważnie, przynajmniej w paru istotnych aspektach. Ta potrzeba refleksji wynika także z samego charakteru tez składających się na pogląd biocentryczny. Otóż wywołują one kontrowersje i w ten sposób skłaniają do pogłębionego namysłu. Można więc w nich dostrzec - $\mathrm{z}$ jednej strony - obecność wątpliwych twierdzeń, które domagają się spojrzenia krytycznego. Z drugiej jednak strony, tezy te sygnalizują obecność pewnych istotnych przesłanek, które muszą być przyjęte, kiedy podejmuje się integralną refleksję na temat człowieka i jego miejsca w naturalnym świecie.

Zaczynając od tego drugiego spojrzenia, należy stwierdzić, że istotę ludzką wiele łączy ze środowiskiem, co znajduje swój rezonans w myśleniu omawianego filozofa. Człowieka rzeczywiście można uznać za członka jednego z gatunków zamieszkujących ziemię. Pośród żyjących istot jawi się on jako jeden z organizmów biologicznych, choć - co należy zauważyć - jest kimś więcej niż organizmem biologicznym. Warunki środowiskowe, w jakich funkcjonuje jednostka ludzka, są wspólne wszystkim istniejącym organizmom. Człowiek przebywa podobne etapy powstawania, rozwoju i przemijania; ulega różnym chorobom i dalszym uwarunkowaniom środowiskowym, podobnie jak zwierzęta. Stąd powiedzenie, że istota ludzka jest zwierzęciem pewnego typu jawi się jako w pewien sposób uzasadnione ${ }^{32}$.

Również stwierdzenie, że gatunek ludzki żyje w pewnej zależności nie tylko od generalnie rozumianego środowiska, ale od konkretnych gatunków, czy to roślinnych, czy zwierzęcych, jest oczywiste. Człowiek nie tylko wprost potrzebuje określonych istot żyjących do przetrwania, jako źródła pokarmowego, ale i wielokrotnie korzysta z tego, co inne gatunki wnoszą do środowiska naturalnego. Jego życie ma większe szanse na pomyślny rozwój, kiedy harmonia $\mathrm{z}$ innymi gatunkami jest niezakłócona, albo kiedy potrafi on eliminować i naprawiać wkradające się tu nieprawidłowości.

32 Teza ta będzie bliska zapewne biologom, ale i części filozofów, począwszy od Arystotelesa. We współczesnej wersji myślenia arystotelesowskiego tezą o człowieku jako o zwierzęciu operuje na przykład Patrick Lee. Tytuł jednego z rozdziałów jego książki brzmi: „Human Beings Are Animals”. Zob. P. Lee, R. P. George, Body-Self Dualism on Contemporary Ethics and Politics, New York 2008, s. 4-49. 
Teza, że każdy organizm jest teleologicznym centrum życia, które dąży do realizacji własnego dobra, rozumianego jako cel, także nie budzi większych kontrowersji. Biolog będzie skłonny przyznać temu rację, stwierdzając, że wszystkie organizmy, zgodnie z przynależnością do określonych gatunków, mają swoje etapy rozwoju i do naturalnego biegu rzeczy należy to, że je osiągają (choć niekiedy wkradają się tu pewne anomalie), przez co na przykład można określić wiek ich życia. Filozof również zgodzi się $\mathrm{z}$ tym, że dana istota zdąża do swojego celu (telos) i cel ten jest pewnym dobrem (spełnieniem istnienia). Takie utożsamienie dobra i celu pojawia się chociażby u Arystotelesa ${ }^{33}$. Ten cel-dobro, choć określony istotowo dynamiką danego gatunku, znajduje jednak swoją konkretyzację u danej jednostki. Ona to zdąża do swego spełnienia i niejednokrotnie dokonuje się to w specyficzny sposób. Tę nieznaczną specyfikę w ramach tendencji ogólnogatunkowych można dostrzec, a przez to stwierdzić, że każda jednostka wykazuje - w jakiś sposób - cechy indywidualne.

Tezy Taylora mogą jednak budzić również poważne wątpliwości. Pojawiają się one zasadniczo przy tezie czwartej. Filozof ten mówi, że typowo ludzkie cechy nie mogą być miarą do określania wartości istot pozaludzkich. Te istoty muszą być oceniane według własnych kategorii. Ani właściwa człowiekowi rozumność, autonomia, ani kreatywność estetyczna czy wolna wola nie mogą prowadzić nas do wniosku, że fakt ich nieposiadania przez zwierzęta i rośliny pomniejsza ich status aksjologiczny. W aspekcie wewnętrznym - prezentowanym dotychczas - wydaje się to uzasadnione. Każde istnienie posiada swój własny telos i on wyznacza to, co jest konieczne do jego osiągnięcia. Można powiedzieć, że to, jak dane istnienie dąży do własnego dobra i jak je spełnienia, jest miarą jego wartości, a nie to, jak się prezentuje w świetle telosu innego istnienia.

Rygorystyczne przestrzeganie tego wymogu nakazuje jednak powstrzymywanie się $\mathrm{w}$ dokonywaniu jakichkolwiek porównań pomiędzy różnymi istotami żyjącymi. Chodziłoby tu nie tylko o zaprzestanie

${ }^{33}$ Filozof ten mówi o dobru jako celu w kontekście ludzkiego działania (zob. Arystoteles, Etyka nikomachejska, tłum. D. Gromska, Warszawa 2000, nr 1094A), jednak wydaje się, że generalnie można to odnieść także do naturalnego stawania się. 
wydawania sądu, że człowiek jest kimś wyższym i lepszym niż zwierzęta i rośliny, czy odwrotnie, czyli powstrzymanie się od pozytywno-negatywnych wartościowań międzygatunkowych. Konieczne byłoby również zaprzestanie wydawania jakiegokolwiek sądu oceniającego. Taylor jednak taki sąd wydaje. W swojej bowiem konkluzji filozof ten formułuje zasadę równości gatunkowej, czyli wskazuje na konieczność uznania, że wszystkie gatunki posiadają równą wartość ${ }^{34}$. Jest to stanowisko egalitaryzmu aksjologicznego. $Z$ niego to wyprowadza on nawet swoisty imperatyw określający konieczność zaangażowania się w ochronę i promocję każdego typu istnienia, w sposób bezstronny.

Konsekwentnym działaniem byłoby powstrzymanie się od wypowiadania tezy wartościującej, wykraczającej poza jednostki tego samego gatunku. Można byłoby powiedzieć najwyżej, że jeden szympans jest doskonalszy od drugiego, ponieważ lepiej realizuje cel-dobro tego gatunku. Natomiast nie należy porównywać szympansa do człowieka. Nie można więc powiedzieć, że jest on lepszy, gorszy czy równy wartością człowiekowi. Najlepiej byłoby powiedzieć, że jest różny. Taką też konkluzję przedstawia David Schmidtz, komentując tezy Paula Taylora. Twierdzi on, że można zaakceptować trzy pierwsze, nie akceptując czwartej. Uznanie, że jesteśmy członkami ziemskiej wspólnoty życia, która polega na szerokiej sieci relacji z innymi istotami i stanowimy teleologiczne centra życia, wcale nie musi nas prowadzić do wniosku o równości z całą biosferą. Opowiedzenie się bowiem za tezą o równości nie jest jedyną drogą do poszanowania innych istot. Wystarczy bowiem uznać je za odmienne stworzenia, posiadające swój telos i dobro, aby podejmować działania pełne troski i szacunku względem nich ${ }^{35}$.

34 Rozważania Paula Taylora mogłyby doprowadzić do innych wniosków. W uzasadnieniu swoich tez wskazywał on bowiem na słabości Homo sapiens: pojawił się późno na świecie, zdominował inne gatunki i niszczy biosferę, jego odejście będzie pewną formą uzdrowienia całości ziemskiej wspólnoty życia. Z tego wynikałoby, że lepiej uznać człowieka za gatunek podejrzany i nie przyznawać mu statusu równości z innymi istotami. W tej perspektywie, można uznać go, po prostu, za gorszą część środowiska naturalnego.

${ }_{35}$ Zob. D. Schmidtz, Are All Species Equal?, [w:] Environmental Ethics. What really Matters, What really Works, red. D. Schmidtz, E. Willott, New York 2002, s. 96 n. 
Innym zarzutem, który można wysunąć pod adresem tez Taylora jest pojawiająca się niewspółmierność poszczególnych twierdzeń. Ostatnie z nich, dotyczące równości gatunkowej, ma najwyraźniej charakter totalny: wyraża ono przekonanie dotyczące statusu wszystkich gatunków. Jednak to, co do tej tezy prowadzi, mianowicie istotne przesłanki, jest uzyskane drogą selektywnego doboru. Otóż Taylor - z jednej strony - wyraźnie odsuwa na plan dalszy pewne ważne aspekty wolnego i rozumnego działania człowieka. Z drugiej jednak strony nakazuje nam dokonanie integralnego spojrzenia na rośliny i zwierzęta, uznając je za istnienia wieloaspektowe (w trzeciej tezie). Filozof dokonuje tego zabiegu, aby podkreślić jedynie te cechy, które łączą nas, ludzi ze zwierzętami i roślinami ${ }^{36}$. Jest to forma częściowego redukcjonizmu (w stosunku do części istot - istot Homo sapiens) i najwyraźniej jest ona przeprowadzona celowo. Można więc zapytać, czy taka wybiórcza prezentacja istoty ludzkiej pozwala na wyciągnięcie tak daleko sięgającego wniosku. Wygląda bowiem na to, że przesłanki pod to ostatnie twierdzenie zostały celowo przygotowane, czyli filozof ten już w punkcie wyjścia mógł znać wniosek końcowy.

W tym kontekście Schmidtz zarzuca Taylorowi nieuzasadniony minimalizm i wybiórczość przesłanek w formułowaniu tez stanowiska biocentrycznego. Schmidtz twierdzi, że nieuzasadnione jest posunięcie polegające, po pierwsze, na wyszczególnieniu cech, które łączą wszystkie żyjące istoty; następnie na wysunięciu tezy, że tylko one mają moralne znacznie; i w końcu na stwierdzeniu, że $z$ tego powodu wszystkie żyjące stworzenia są równe co do wartości. Mogą bowiem istnieć także inne cechy, będące w posiadaniu tylko niektórych istot, decydujące o odmiennym statusie aksjologicznym ${ }^{37}$. Coś takiego zachodzi u człowieka. To, co Taylor zredukował - w aspekcie wyższych funkcji ludzkiej wolności, rozumności czy estetycznej kreatywności - może być tym, co faktycznie uzasadnia odmienny status aksjologiczny człowieka.

36 Taylor wprost stwierdza: „We do not deny the differences between ourselves and other species [...], we keep in the forefront of our consciousness the characteristics we share with all forms of life on Earth" (P. W. Taylor, Respect for Nature..., dz. cyt., s. 101).

37 Zob. D. Schmidtz, Are All Species..., dz. cyt., s. 98. 


\section{W stronę pluralizmu aksjologicznego}

W jaki sposób można byłoby poznać ten odmienny status aksjologiczny i w jaki sposób go ukazać? Otóż wydaje się uzasadnione przyjęcie założenia, że owa odmienność posiadanych dóbr jest czymś wewnętrznie uwarunkowanym. Jest ona efektem obecności w każdym istnieniu ożywionym wewnętrznej wartości ontycznej ${ }^{38}$. Aby nie popełnić błędu naturalistycznego, dobrze byłoby przyjąć, że wartość ta nie jest jakością naturalną ani czymś z niej wyprowadzonym ${ }^{39}$. Jedno towarzyszy drugiemu, ale stwierdzenie ich obecności to $\mathrm{w}$ istocie dwa odmienne typy orzeczeń. Poznanie stanów naturalnych to zwykle zdobycie pewnej informacji; poznanie wartości to ujęcie ważności danego istnienia. Personaliści w tej kwestii twierdzą, że poznając daną rzecz w aspekcie empiryczno-informacyjnym, zawsze ujmuje się również jej stan aksjologiczny ${ }^{40}$. Informują o tym zainteresowanego stany poznawczo-emocjonalne. Poznając coś, zawsze kształtujemy sobie nie tylko pogląd (jako zbiór informacji), ale i odniesienie emocjonalne do tego czegoś, jakąś postawę emocjonalną. To coś nabiera dla nas zawsze pewnego znaczenia, odsłania się nam jako pewna ważność (taka czy inna, wyższa bądź niższa). Niejednokrotnie dzieje się to w ten sposób, że im głębiej bada się daną rzecz w aspekcie empirycznym, tym bardziej odsłania się naszej intuicji odnośna wartość. Zbierając informacje o czymś, równocześnie nabywamy poczucia znaczenia i wagi tegoż.

W wypadku roślin, zwierząt, a zwłaszcza ludzi jest to szczególnie ważne. Nigdy istoty te nie jawią się nam jako czyste stany rzeczy czy

38 Zob. W. Galewicz, O dobru drzew i ekologicznej reformie utylitaryzmu, [w:] Świadomość środowiska, red. W. Galewicz, Kraków 2006, s. 41.

39 Nie ma pewności, czy Taylor poczyniłby takie założenie. Otóż jego rozważania o wewnętrznej wartości mocno zbliżają się do orzeczeń o cechach naturalnych: posiadanie wewnętrznej wartości na mocy przynależności do wspólnoty biotycznej naturalnego ekosystemu. Zob. P. W. Taylor, Respect for Nature..., dz. cyt., s. 78n. Nie doszłoby tu do błędu naturalistycznego, gdyby wykazano, że wspólnota biotyczna naturalnego ekosystemu cechuje się dobrem samym w sobie, a nie jest tylko pewną faktycznością, stanem naturalnym.

${ }_{40}$ Zob. J. Merecki, Naturalizm etyczny. Błąd naturalistyczny, [w:] Powszechna encyklopedia filozofii, red. A. Maryniarczyk, t. 7, Lublin 2006, kol. 531n. 
zbiór informacji. Zawsze ujmujemy je jako pewne dobra-wartości, i to ujęcie choć towarzyszy poznaniu empirycznemu, nie jest jednak jego pochodną: pojawia się niejako przy okazji procesu gromadzenia informacji. Postawa poczucia ważności „buduje się" w nas zatem równolegle, $\mathrm{w}$ innej sferze poznania-doświadczenia.

Następnie należy stwierdzić, że skoro istoty żyjące jawią się jako pewne wartości, to te stany aksjologiczne domagają się adekwatnego wytłumaczenia, czyli podania racji. Inaczej mówiąc, skoro uderzające jest to, że istoty ożywione prezentują się jako pewne dobra, to musi się znaleźć jakieś wytłumaczenie dla tego doświadczenia. Personaliści, na przykład w odniesieniu do człowieka, powiedzą, że racji dla doświadczeń aksjologicznych może dostarczyć refleksja antropologiczna. Jak stwierdza Tadeusz Styczeń: „antropologia [...] jest racją dla tez etycznych, lecz nie przesłanką dla nich, to one są dla niej przesłanką [...],

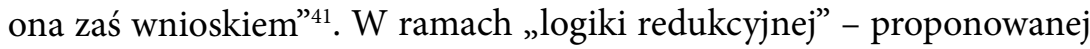
przez tego filozofa - punktem wyjścia jest doświadczenie szczególnej wartości człowieka, które budząc zdziwienie (a w praktyce powodując pewną uciążliwość - „apelując” o zmianę postępowania), domaga się wyjaśnienia. Choć dane, nie jest ono samozrozumiałe. W oczywisty więc sposób pobudza do poszukiwania racji.

Jeśli [...] racją tą - kontynuuje Styczeń - okaże się „natura ludzka”, to jej przyjęcie będzie nade wszystko sprawą przyjęcia tego, co jest w stanie jedynie i ostatecznie tłumaczyć - lub inaczej mówiąc: uniesprzecznić fakt tej treści, o jakim informuje doświadczenie moralności ${ }^{42}$.

Koncepcja człowieka, podejmując zagadnienie natury ludzkiej, stwarza możliwość dostarczenia racjonalnego wytłumaczenia dla jawiącej się cenności człowieka. Wydaje się uzasadnione, aby analogicznie orzekać o roślinach i zwierzętach: ich dobro-wartość może znaleźć swoje ostateczne uniesprzecznienie w strukturze ich istnienia, choć - jak

${ }_{41}$ T. Styczeń, Antropologia a etyka, [w:] tenże, W drodze do etyki, Lublin 1984, s. 126.

42 Tamże. 
w wypadku człowieka - wartość ta nie jest z niej wyprowadzana czy dedukowana: jest ona dana w bezpośrednim przeżyciu.

Doświadczenia aksjologiczne związane $\mathrm{z}$ istnieniem roślin, zwierząt czy istot ludzkich właściwie same powinny nam komunikować, która istota jest doskonalsza. W większości wypadków tak się dzieje; ludzie zwykle mają dosyć jednoznacznie przekonanie, że wartości te układają się w następującą hierarchię: najpierw człowiek, później zwierzę, a w końcu roślina. Ta hierarchia wynikająca $z$ intuicyjnego odczytania istoty każdego stworzenia może być następnie tłumaczona (uniesprzeczniana drogą podawania racji ostatecznych) poprzez odwołanie się do natury rośliny, zwierzęcia i w końcu człowieka.

Może być jednak i tak, że ta recepcja aksjologiczna jest niejasna, a nawet zakłócona, $\mathrm{z}$ różnych powodów ${ }^{43}$. Może tu więc powstać spór o to, czy rzeczywiście - powiedzmy - człowiek jest cenniejszy od szympansa. Na poziomie recepcji dobra-wartości rozwiązanie tego sporu może być niemożliwe. Dyskutujące strony będą bowiem deklarowały odmienne doświadczenia aksjologiczne. Jedynym sposobem zniwelowania rozbieżności będzie powiedzenie, iż jedna z dyskutujących stron źle poznała wartość i mamy tu do czynienia z iluzją aksjologiczną, albo nawet $\mathrm{z}$ daltonizmem aksjologicznym. Podejście to nie jest jednak zadawalające. Niewiele ono rozwiązuje, wskazując na niedojrzałość poznawczą i emocjonalną jednej ze stron (chociaż uzasadnione jest twierdzenie, że ktoś się myli).

Konieczne jest rozstrzygnięcie tego sporu poprzez sięgnięcie do racji, które uzasadniałby taką czy inną tezę o dobru-wartości. Same racje choć nie wyłaniają doświadczeń aksjologicznych, to jednak mogą być potwierdzeniem, że to a nie tamto doświadczenie jest prawdziwe. Doświadczenie fałszywe (jako wynik iluzji aksjologicznej) nie będzie miało odpowiednich racji ostatecznych. Nie będzie niczego, co je uzasadnia albo uzasadnia adekwatnie. Co więcej, łatwiej jest przeprowadzić

43 Mogą to być powody kulturowe (absolutyzacja myślenia ewolucyjnego i wypływających z niego wniosków) czy nawet światopoglądowe (religijne lub quasi-religijne przekonania o równości stworzeń), które sprawiają, że „rozmywa się” ta hierarchia aksjologiczna. 
konfrontację pomiędzy racjami (poprzez określenie siły argumentu) niż między doświadczeniami aksjologicznymi. Racje mogą być na tyle prześwietlone poznawczo, że da się je podzielić na lepsze i gorsze, właściwe i pozorne. Na tym gruncie, jak się wydaje, możliwa byłaby intersubiektywnie wiarygodna debata.

Rozstrzygnięcie sporu - załóżmy pomiędzy naturalistami a personalistami - o to, kto jest cenniejszy, człowiek czy szympans, może się więc dokonać nie na płaszczyźnie porównania i konfrontacji odnośnych doświadczeń aksjologicznych, ale poprzez przejście do analizy ich (człowieka i szympans) natury i uzyskanych tą drogą odpowiednich racji. Racje te staną się jakąś formą weryfikacji skonfliktowanych doświadczeń. Ujawnią, które są adekwatne, a które nie. W przeciwieństwie do pierwszego typu poznania, któremu towarzyszyły skonfliktowane przeżycia aksjologiczne, poszukiwanie racji musi być dokonane w sposób systematyczny i dogłębny. Należy unikać przyjmowania założeń czy wstępnych redukcji, które apriorycznie zacieśniałyby pole poznania, jak to miało miejsce u Paula Taylora.

Odwołanie się do integralnej struktury konkretnych istnień (roślinnego, zwierzęcego i ludzkiego) stwarza więc szansę na uzasadnienie zróżnicowanego statusu aksjologicznego i sformułowanie odpowiednich praw i obowiązków. Jest to metoda, która może być bardzo pomocna na drodze od stanowiska egalitaryzmu aksjologicznego biosfery do stanowiska aksjologicznego pluralizmu, które bardziej adekwatnie oddaje bogactwo świata, w którym żyjemy. 